\title{
INTRODUCING BUSINESS STUDIES
}




\title{
INTRODUCING \\ BUSINESS STUDIES
}

SECOND EDITION

\author{
Joseph Chilver
}


(C) Joseph Chilver 1979, 1984

All rights reserved. No part of this publication may be reproduced or transmitted, in any form or by any means, without permission

\author{
First edition 1979 \\ Reprinted 1982 \\ Second edition 1984 \\ Published by \\ Higher and Further Education Division \\ MACMILLAN EDUCATION LTD \\ Houndmills, Basingstoke, \\ Hampshire, RG21 2XS, \\ and London \\ Companies and representatives \\ throughout the world
ISBN 978-1-349-07364-1 ISBN 978-1-349-07362-7 (eBook)
DOI 10.1007/978-1-349-07362-7




\section{Contents}

\section{PART 1 INTRODUCTION}

1 An Introduction to the Case-study Concept 3

2 A Specimen Case Study for Analysis 7

3 The Assessment of Individual Performances 14

4 An Explanation of What Follows 20

PART 2 ON THE THEME OF PEOPLE AND COMMUNICATION AT WORK...

5 Basic Industrial Psychology 27

6 The Personnel Department 35

7 Recruitment and Selection 44

8 Remuneration 52

9 Labour Turnover 59

10 Morale 65

11 Communication 71

12 Committee Meetings $\quad 75$

13 Trade Unions $\quad 80$

14 Industrial Unrest 85

15 Resistance to Change 89

16 Further Case Studies on the People Theme 94

\section{PART 3 ON THE STRUCTURE OF BUSINESS}

17 The Forms of Business Organisation 101

18 Organisation Structures 110 
19 Production 115

20 Economies of Scale $\quad 121$

21 Marketing 125

22 Advertising 133

23 Distribution 139

24 Transport 148

25 The Office Function 155

26 The Accounting Function 168

27 The Functions of Management 176

28 Further Case Studies on Business Organisation 184

\section{PART 4 ON THE THEME OF MONEY}

29 Sources of Business Finance 193

30 The London Stock Exchange 203

31 The Banking System 210

32 Exchange Rates 220

33 Insurance 225

34 Government and Business 232

35 The European Economic Community 239

\section{PART 5 CROSS-MODULAR CASE STUDIES}

36 Boardroom Problems 244

37 In-tray 1-Marketing Department 246

38 Wife-testing 255

39 In-tray 2-Gifford Electronics 258

40 The Royalty Grill 262

41 Trade Secrets 264

42 Northfield United 266

43 Tropical Aquaria 268

44 The New Store Manager 270

45 The Bank Absentees 273

46 The Credit Control Department 275

47 Funds for Expansion 278

48 Executive Stock Options 280

49 Crypto Investment Projects 283

50 RentaVan Ltd 286

51 Olympic Finances $\quad 289$

52 In-tray 3 - The Registrar's Department 291

$\begin{array}{lll}\text { PART } 6 \text { GUIDELINES } & 295\end{array}$

Select Bibliography $\quad 337$ 


\section{Preface}

There is a basic area of study which is required in all business courses and it is this common core of commercial knowledge which has been collated here. Business Education Council courses remain a prime target for this new edition but the lecture notes have been extended for the benefit of secretarial students. These now cover the syllabus and course specifications for the Background of Business and the Structure of Business for Royal Society of Arts and London Chamber of Commerce and Industry examinations.

Although the characters and companies are fictitious, the case-study scenarios are based on real-life business situations.

My thanks are extended to the Macmillan Press for permission to reproduce a part of the illustration from pp. 12-13 of Further Education College Catalogue 1983: Arts \& Business Education.

Joserh Chilver 